\title{
13 The economic impact of the ASEAN-China Free Trade Area A computational analysis with special emphasis on agriculture
}

\section{Jun Yang and Chunlai Chen}

Trade between China and the Association of South-East Asian Nations (ASEAN) has increased very rapidly in the past decade. Total trade (imports plus exports) between China and ASEAN expanded 6.7 times, from US\$19.3 billion in 1996 to US\$105.1 billion in 2005-an annual growth rate of 21 per cent. Currently, China is ASEAN's third largest trading partner, and ASEAN is China's fourth largest trading partner. As the growth rate of China's imports from ASEAN is higher than that of its exports to the regional group, China's trade status with ASEAN has changed from a trade surplus to a trade deficit, and the deficit has been rising in recent years. In 2005, China's trade deficit with ASEAN reached US\$19.8 billion.

The trading relationship between China and ASEAN is expected to become closer because of the establishment of the ASEAN-China Free Trade Agreement (ACFTA). The Framework Agreement on ASEAN-China Comprehensive Economic Cooperation was signed in 2002, and represented a milestone in cooperation between the two economies. The ACFTA is scheduled to enter into force in $2010 .{ }^{1}$ With a view to accelerating the implementation of the agreement, the parties agreed to implement an Early Harvest Program (EHP) with a package of agricultural and industrial products. The EHP committed the participating countries to the elimination of tariffs on these products between 2004 and 2006. ${ }^{2}$ 
Recent studies have shown that economic integration between China and ASEAN will bring numerous opportunities as well as challenges for the participants. Some studies show that China and ASEAN will experience net trade gains from the ACFTA and that it will promote economic growth in both economies (Chirathivat 2002; ASEAN Joint Experts Group 2001). In contrast, some studies find that China and ASEAN will be more likely to compete with, rather than complement, each other (Tongzon 2005; Holst and Weiss 2004; Voon and Yue 2003; Wong and Chan 2002). As the ACFTA will likely increase the competitive pressures on ASEAN producers in third-country markets and in ASEAN domestic markets, some special and differential treatment has been seen as necessary for the poorer ASEAN economies (Wattanapruttipaisan 2003). Studies have, however, pointed out that China's market liberalisation under the ACFTA would provide ASEAN countries with promising economic opportunities (Tongzon 2005; Holst and Weiss 2004). Moreover, both economies would gain large benefits from becoming more competitive and attracting foreign investment into their integrated market in the long run (Wong and Chan 2003).

These different views certainly raise issues worthy of further study. Moreover, many empirical studies have shown that regional free trade agreements contribute to member countries' growth through the accumulation of physical and human capital, productivity growth and accelerated domestic reforms (for example, Ethier 2000; Fukase and Winters 2003), but that it cannot be assumed that all participants and sectors will benefit equally. Some could, in fact, be hurt by the liberalisation. Moreover, the realisation of the ACFTA is a complex procedure involving several steps. It is useful, therefore, to study the effects under different policy arrangements during the different stages. There has been no study focusing on the dynamics of the agreement. Therefore, one of the main aims of this chapter is to explore the different economic effects of the EHP during 2004-06 and the full implementation of the ACFTA in 2010.

\section{Trade liberalisation in China and ASEAN}

Because the major issue in a free trade agreement is tariff reduction, accurate estimation of the tariffs used by the participants is very important. In this 
section, we analyse the trade liberalisation schedules in China and ASEAN, examining China's World Trade Organization (WTO) commitments, ASEAN Free Trade Area (AFTA) commitments and the ACFTA commitments.

\section{China's WTO commitments}

After 15 years of arduous negotiations, China acceded to the WTO at the end of 2001. As a result of the negotiations, China has agreed to undertake a series of commitments to liberalise its trade policy in order to better integrate into the world economy and offer a predictable environment for trade and foreign investment in accordance with WTO rules. ${ }^{3}$ Under its WTO commitments, China will further reduce its import tariffs on goods and reduce or eliminate trade barriers on services. Other prohibitions, quantitative restrictions or protective measures used against imports that are inconsistent with WTO agreements will be phased out or otherwise dealt with in accordance with mutually agreed terms.

Import tariffs will be reduced gradually between 2001 and 2010. Based on the Harmonised Commodity Description and Coding System (HS) tariff schedules of the protocol of China's WTO accession and weighted by 2001 import data from the United Nations Statistics Division, Commodity Trade Statistics Database (COMTRADE), China's average import tariff will be reduced gradually from 8.79 per cent in 2001 to 5.43 per cent in 2010. ${ }^{4}$ The scheduled import tariff reductions-by commodity and year-are provided in Table A13.1. As there is no tariff line in the services sector, it is difficult to estimate the liberalisation directly. In the empirical analysis, we adopt the estimate of Tongeren and Huang (2004) and Francois and Spinager (2004) that the import tariff equivalent of China's services sector will be reduced from 19 per cent to 9 per cent.

China will confront considerable challenges in its liberalisation of the agricultural sector. In addition to the agreed tariff reductions, China committed to removing quantitative restrictions, phasing out all export subsidies and reducing product-specific support to 8.5 per cent. ${ }^{5}$ Although China's WTO agreement allows the government to manage the trade of 'national strategic products' through a tariff rate quota (TRQ), the quotas under low tariffs will be expanded while the shares of state-owned enterprises (SOEs) will be reduced gradually. 
The details of China's TRQs in agricultural products are shown in Table 13.1. The within-quota tariffs are quite low, while the out-of-quota tariffs are almost prohibitive. For example, the in-quota tariff for sugar is 20 per cent, while it is 9 per cent for edible oils and only 1 per cent for rice, wheat, maize and wool. The quantities imported at these low tariff levels are limited; however, the in-quota volumes were to grow over a four-year period (2002-05) at annual rates ranging from 4 per cent to 19 per cent. At the same time, tariffs on out-of-quota imports and import shares for SOEs would be reduced substantially between 2002 and 2005 .

\section{AFTA's tariff reduction schedule}

The ASEAN Free Trade Area (AFTA) was established in January 1992 with the objective of eliminating tariff barriers among ASEAN member countries. The Agreement on the Common Effective Preferential Tariff (CEPT) Scheme for the AFTA requires that tariff rates levied on a wide range of products traded within the region will be reduced to no more than 5 per cent. Quantitative restrictions and other non-tariff barriers are to be eliminated. The free trade agreement covers all manufactured and agricultural products; however, 734 tariff lines on the General Exception List-representing 1.09 per cent of all tariff lines in ASEAN-are permanently excluded from the agreement for reasons of national security (ASEAN Secretariat 2002).

ASEAN member countries have made good progress in lowering intraregional tariffs. More than 99 per cent of the products in the CEPT Inclusion List of ASEAN+6 have been brought down to the $0-5$ per cent tariff range (Figure 13.1). ASEAN's new members have also reduced their import tariffs, with almost 80 per cent of their products having been moved into their respective CEPT inclusion lists. Of these items, about 66 per cent already have tariffs within the $0-5$ per cent band. Vietnam had until 2006 to bring down tariffs of products on its inclusion list to no more than 5 per cent; Laos and Myanmar have until 2008, and Cambodia until 2010.

According to the amending protocol ${ }^{7}$ signed by ASEAN member states in 2003, import duties on products on the inclusion lists of Brunei, Indonesia, Malaysia, the Philippines, Singapore and Thailand will be eliminated no later than 1 January 2010. Import duties on products on the inclusion lists for Cambodia, Laos, Myanmar and Vietnam will be eliminated no later 
than 1 January 2015, with flexibility allowing for import duties on some sensitive products to be eliminated no later than 1 January 2018. The tariff reduction schedule for sensitive products is governed by the Protocol on the Special Arrangement for Sensitive and Highly Sensitive Products; however, all sensitive products will have final tariff rates of 0-5 per cent by the deadlines agreed for each country. ${ }^{8}$

\section{Table 13.1 China's market access commitments on farm products subject to TRQs}

\begin{tabular}{|c|c|c|c|c|c|c|}
\hline & \multicolumn{2}{|c|}{ Share of SOE (\%) } & \multicolumn{4}{|c|}{ Quotas by year } \\
\hline & 2002 & Terminating year & 2002 & 2003 & 2004 & 2005 \\
\hline Wheat & 90 & 90 & 8.468 & 9.052 & 9.636 & -- \\
\hline Corn & 71 & 60 & 5.850 & 6.525 & 7.200 & -- \\
\hline Rice & 50 & 50 & 1.995 & 2.328 & 2.660 & -- \\
\hline Soybean oil & 42 & 10 & 2.518 & 2.818 & 3.118 & 3.587 \\
\hline Palm oil & 42 & 10 & 2.400 & 2.600 & 2.700 & 3.168 \\
\hline Rape-seed oil & 42 & 10 & 0.879 & 1.019 & 1.127 & 1.243 \\
\hline Sugar & 70 & 70 & 1.764 & 1.852 & 1.945 & -- \\
\hline Wool & n.a. & n.a. & 0.265 & 0.276 & 0.287 & -- \\
\hline \multirow[t]{3}{*}{ Cotton } & 33 & 33 & 0.819 & 0.856 & 0.894 & -- \\
\hline & \multirow{2}{*}{\multicolumn{2}{|c|}{ In-quota tariff }} & \multicolumn{4}{|c|}{ Out-of-quota tariff } \\
\hline & & & 2002 & 2003 & 2004 & 2005 \\
\hline Wheat & & 1 & 71 & 68 & 65 & -- \\
\hline Corn & & 1 & 71 & 68 & 65 & -- \\
\hline Rice & & 1 & 74 & 71 & 65 & -- \\
\hline Soybean oil & & 9 & 75 & 71.7 & 68.3 & 65 \\
\hline Palm oil & & 9 & 75 & 71.7 & 68.3 & 65 \\
\hline Rape-seed oil & & 9 & 75 & 71.7 & 68.3 & 65 \\
\hline Sugar & & 20 & 90 & 72 & 50 & -- \\
\hline Wool & & 1 & 38 & 38 & 38 & -- \\
\hline Cotton & & 1 & 54.4 & 47.2 & 40 & -- \\
\hline
\end{tabular}

n.a. there is no information in the proposal

-- the TRQ regime was phased out in 2004

Source: World Trade Organization, 2001. Accession of the People's Republic of China, decision of 10 November 2001, World Trade Organization, Geneva. 
The free trade agreement between ASEAN and China (ACFTA)

The ACFTA was proposed initially by then Chinese Premier, Zhu Rongji, at the ASEAN-China summit in November 2000. The framework agreement on comprehensive economic cooperation between China and ASEAN nations was signed on 4 November 2002, and represented a milestone in cooperation between the two parties. According to the time frame provided by the agreement, the ACFTA covering trade in goods will be established by 2010 for Brunei, China, Indonesia, Malaysia, the Philippines, Singapore and Thailand, and by 2015 for the new ASEAN member states, Vietnam, Laos, Cambodia and Myanmar.

With a view to accelerating the implementation of the framework agreement, the parties agreed to implement the EHP for a package of agricultural and industrial products. Starting in 2004, the EHP committed the countries to the elimination of tariffs on these products by 2006. As shown in Table 13.2, the EHP comprises agricultural products under HS Chapters 1-8. The original ASEAN members and China reduced the import tariffs on these commodities to zero before 1 January 2006. The newer ASEAN members enjoy a longer period before they are to eliminate tariffs on these commodities. ${ }^{9}$

According to the trade-in-goods agreement, participating countries will eliminate tariffs and non-tariff barriers substantially for all products traded over time. For ASEAN +6 and China, the schedule for the bulk of the goods subject to tariff elimination ranges from 2005-10. The newer ASEAN members have until 2015 to remove all import tariffs. Countries have the flexibility to protect a limited number of products that are considered sensitive for their economies; however, the tariffs on most of these products will be reduced to 0-5 per cent by 2018 .

\section{Methodology and policy scenarios}

The main analytical tool used in this study is a global trade model based on the Global Trade Analysis Project (GTAP). Following a brief introduction of the model, efforts to enhance GTAP's database and parameters for China are discussed. Finally, the baseline and two policy scenarios are defined for the purposes of evaluating the effects of the EHP during 2004-06 and the full implementation of the ACFTA during 2006-10. 
Figure 13.1 Percentage of tariff lines at 0-5 per cent in the tentative 2004 CEPT package

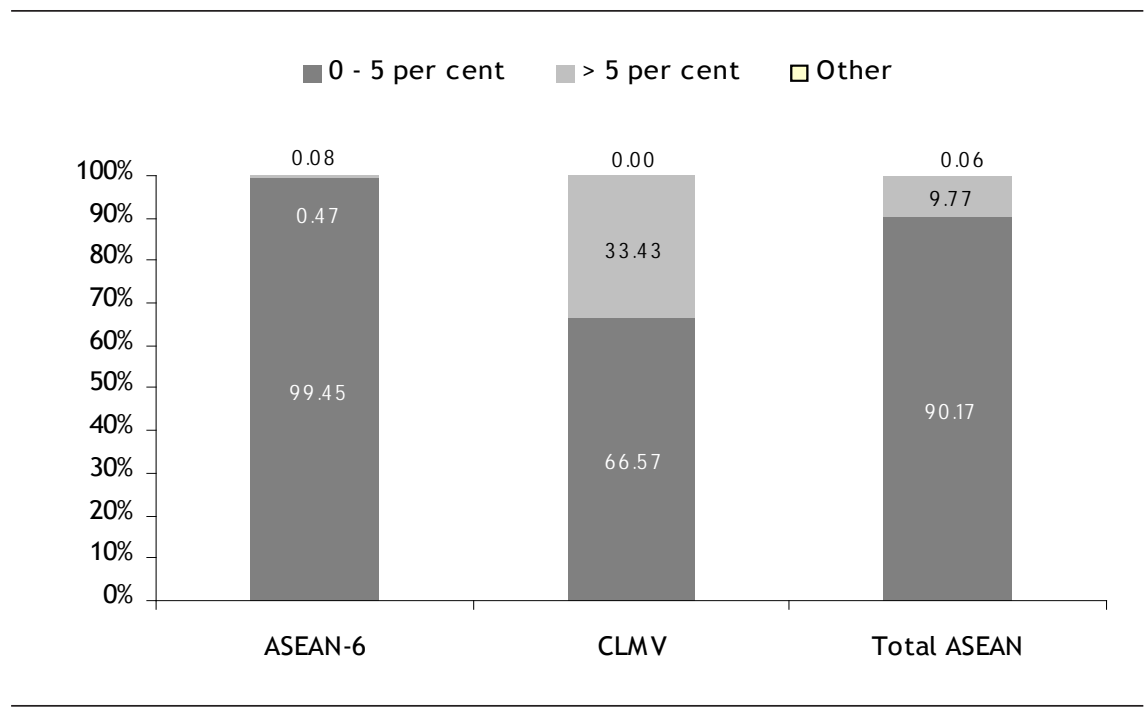

Source: ASEAN statistics, 2005. Available online at http://www.aseansec.org

Table 13.2 Product coverage in the Early Harvest Program (EHP)

$\begin{array}{cl}\text { Chapter } & \text { Description } \\ 01 & \text { Live animals } \\ 02 & \text { Meat and edible meat offal } \\ 03 & \text { Fish } \\ 04 & \text { Dairy products } \\ 05 & \text { Other animal products } \\ 06 & \text { Live trees } \\ 07 & \text { Edible vegetables } \\ 08 & \text { Edible fruits and nuts }\end{array}$

Source: ASEAN-China FTA Framework Agreement (2002). Available online at http://www. bilaterals.org 
Brief introduction to the GTAP model

GTAP is a multi-region, multi-sector, computable general equilibrium model, with perfect competition and constant returns to scale. The model is described fully in Hertel (1997). It has been used widely to analyse the impacts of changes in trade policy.

In the GTAP model, each country or region is depicted within the same economic structure. The consumer side is represented by the country or regional household to which are assigned the income of factors, tariff revenues and taxes. The country or regional household allocates its income to three expenditure categories: private household expenditure, government expenditure and savings. For the consumption of the private household, the non-homothetic Constant Difference of Elasticities (CDE) function is applied. Firms combine intermediate inputs and primary factors, land, labour (skilled and unskilled) and capital. Intermediate inputs are composites of domestic and foreign components, and the foreign component is differentiated by region of origin (the so-called Armington assumption). With respect to factor markets, the model assumes full employment, with labour and capital being fully mobile within regions but immobile internationally. Labour and capital remuneration rates are determined endogenously at equilibrium. In the case of crop production, farmers make decisions on land allocation. Land is assumed to be imperfectly mobile between crops, and hence the model allows for endogenous land rent differentials. Each country or region is equipped with one country or regional household that distributes income across savings and consumption expenditure to maximise its utility.

The GTAP model includes two global institutions. All transport between regions is carried out by the international transport sector. The trading costs reflect the transaction costs involved in international trade as well as the physical activity of transportation itself. Using transport inputs from all regions, the international transport sector minimises its costs under Cobb-Douglas technology. The second global institution is the global bank, which takes the savings from all regions and purchases investment goods in all regions depending on the expected rates of return. The global bank guarantees that global savings are equal to global investments. 
The model does not have an exchange rate variable; however, by choosing as a numeraire the index of global factor prices, each region's change of factor prices relative to the numeraire directly reflects a change in the purchasing power of the region's factor incomes on the world market. This change can be interpreted directly as a change in the real exchange rate. Welfare changes are measured by the equivalent variation, which can be computed from each region's household expenditure function.

Taxes and other policy measures are represented as ad valorem tax equivalents. These create wedges between the undistorted prices and the policy-inclusive prices. Production taxes are placed on intermediate or primary inputs, or on output. Trade policy instruments include applied most-favoured nation tariffs, anti-dumping duties, countervailing duties, export quotas and other trade restrictions. Additional internal taxes can be placed on domestic or imported intermediate inputs, and can be applied at differential rates that discriminate against imports. Taxes could also be placed on exports and on primary factor income. Finally, where relevant, taxes are placed on final consumption, and these can be applied differentially to the consumption of domestic and imported goods.

\section{Data improvement}

The GTAP database contains detailed bilateral trade, transport and protection data characterising economic linkages among regions. Regions are linked with individual country input-output databases, which account for inter-sectoral linkages among the 57 sectors in each of the 87 regions. The database provides detailed sectoral classifications for agriculture, with 14 primary agricultural sectors and seven agricultural-processing sectors. The base year for the version used in this study (Version 6) is 2001. For the purpose of the study, the database has been aggregated into 13 regions and 22 sectors. The regional and sectoral aggregations are summarised in Tables A13.2 and A13.3.

Before applying the GTAP Version 6, we carefully examined the database and parameters for China and made substantial improvements in several aspects related to agricultural input and output ratios, demand parameters, trade policies and production values. The main improvements to GTAP Version 6 include the following. 
Input-output tables in the agricultural sector. We overcame some of the shortcomings in the database by taking advantage of data that were collected by the National Development and Reform Commission (NDRC) and government organisations. The NDRC collects data on the costs of production of all of China's major crops and livestock industries. The data set contains information on quantities and total expenditure of labour and material inputs as well as expenditure on a large number of miscellaneous costs such as tax, transportation and marketing. Each farmer reports output and the total revenue earned from crops or livestock. The data were used previously in analyses of China's agricultural supply and input demand (Huang and Rozelle 1996; World Bank 1997). Similar methods have been used for other studies (Huang and Yang 2006; Tongeren and Huang 2004). In this way, we ensure the balance and consistency of input-output relationships among sectors.

Improving own-price and income elasticities for China. We incorporated the most up-to-date estimates for price and income elasticities of demand for various foods in China (Fan et al. 1995; Huang and Bouis 1996; Huang and Rozelle 1998). Table A13.4 summarises the major adjustments that have been made. In addition, we assume that income elasticities of demand for various commodities will change as incomes increase. This is an essential assumption for long-term simulations. Based on other empirical studies (Huang and Bouis 1996; Huang and Rozelle 1998), we assume that food income elasticities decline with income growth (Table A13.4). Using information on uncompensated income elasticities and own-price elasticities, we recalibrate the expansion and substitution parameters for the CDE by the method introduced by Liu et al. (1998) and Yu et al. (2003).

Trade distortions. Various studies have estimated the magnitude of agricultural price distortions using available series on domestic and international prices. Unfortunately, the results obtained have varied widely. Huang et al. (2004) adopted a new approach, which estimated the policy impacts from detailed interviews with participants in China's agricultural marketing and trading activities. This approach provides a much clearer indication of the implications of agricultural trade policies than would otherwise be possible. Their results have been used in several recent 
studies on the impacts of WTO accession on China's economy (Bhattasali et al. 2004; Anderson et al. 2004; lanchovichina and Martin 2004). We adjust import and export tariff equivalents of agricultural commodities in the base year (2001) using results from the study by Huang et al. (2004). Details of the adjustments are provided in Table A13.5.

\section{Assumptions for the different scenarios}

The central goal of this study is to assess the economic impacts of the ACFTA during its various stages of implementation. Towards this end, three scenarios have been developed: I) the baseline scenario; II) the EHP policy scenario in 2006; and III) the full implementation of the ACFTA by 2010.

The baseline scenarios. In this study, we compare two trade liberalisations over two different periods: the EHP during 2004-06 and the full implementation of the ACFTA during 2006-10. We construct two baselines (I and II) to evaluate the effects of policy changes in the two periods. Baseline (I) is constructed for the period 2001-06 to capture the effects of the EHP; Baseline (II) incorporates the effects of the EHP during 2001-06 and projects to 2010 in order to isolate the effects of the liberalisation in the second stage.

Both baselines are constructed using a recursive dynamic approach to reflect the changes over time in the endowments of the countries. This procedure has been used in several other studies (for example, Hertel and Martin 1999; Tongeren and Huang 2004). The growth in endowments (GDP, population, skilled and unskilled labour, capital and natural resources) is taken mainly from other similar studies (Huang and Yang 2006; Tongeren and Huang 2004; Walmsley et al. 2000).

The baseline projection also includes a continuation of existing policies and the effectuation of important policy events related to international trade, as they are known to date. The important policy changes are: implementation of the remaining commitments from the General Agreement on Tariffs and Trade (GATT) Uruguay Round agreements; China's WTO accession commitments between 2001 and 2010; the global phase-out of the Multifibre Agreement under the WTO Agreement on Textiles and 
Clothing (ATC) by January 2005; European Union enlargement to include Central and Eastern European countries (CEECs); and the implementation of the AFTA among ASEAN member countries.

The economic effects of the EHP during 2004-06. Under the EHP scenario, all assumptions under the Baseline (I) scenario are held except for the import tariffs on commodities listed in the EHP between China and ASEAN member countries. According to the protocol of the EHP, the import tariffs were to be eliminated in China and the original ASEAN members before 1 January 2006. Therefore, in this simulation, tariffs between China and the old ASEAN members are reduced to zero on the commodities listed in the EHP.

As for the new ASEAN members, there is a longer period for them to reduce their tariffs on commodities listed in the EHP. As the tariffs on many commodities were to be reduced to about 5 per cent by 2006 (Shang 2005), we adopt the simple and reasonable assumption that the import tariffs of commodities listed in the EHP for China's exports to the newer ASEAN members were reduced to 5 per cent in 2006. The import tariffs for the newer ASEAN members' exports to China will be eliminated.

The full implementation of the ACFTA by 2010. Under the scenario of the full implementation of the ACFTA, all assumptions for Baseline (II) are maintained except for the import tariffs between China and ASEAN. According to the trade-in-goods agreement, participating countries will eliminate substantially tariffs and non-tariff barriers for all products traded. For ASEAN+6 and China, the schedule for the bulk of the goods subject to tariff elimination is before 2010. Therefore, tariffs between China and old ASEAN members will be reduced to zero on all commodities that are not included in the EHP.

As for the newer ASEAN members, they have five additional years (until 2015) to remove all import tariff lines, including tariffs on commodities listed in the EHP. Therefore, in this simulation, we assume newer ASEAN members will make no liberalisation except for implementing their commitments in the EHP, but their exports to China will face zero import tariffs.

Comparison of the simulation results with those for the first stage of the EHP will help us understand the impacts of the second stage of liberalisation. 


\section{Simulation results and explanations}

In this section, we present the economic impacts of the EHP during 2004-06 and the full implementation of the ACFTA for other commodities during 2006-10 separately. Some of the economic forces underlying the impacts are analysed.

\section{The economic impacts of the EHP}

The welfare effects of the EHP are presented in Table 13.3, and the participant countries capture the benefits. The ASEAN+5 countries are the biggest winners in terms of the absolute increase in social welfare (US\$56.55 million). Newer ASEAN members are next, with welfare increasing by US\$25.8 million. The newer ASEAN members are, however, the biggest winners in relative terms. China's welfare increase is modest at US\$13.65 million. As for other regions,,$^{10}$ their total welfare declines by US\$77.03 million because of trade diversion effects. As a whole, global welfare rises by US\$18.97 million.

The returns to primary inputs-that is, land, capital and labour-increase in all the EHP countries. As trade liberalisation through the EHP promotes production in all countries, the demand for primary factors increases. Therefore, the price of primary factors rises in the new equilibrium under the assumption of the fixed supply of primary factors. The price of land increases by 0.029 per cent in China, by 0.71 per cent in ASEAN +5 and by 1.57 per cent in the newer ASEAN members. As relatively more unskilled labour is employed in the agricultural sector, the wage increases of unskilled labour are greater than for skilled labour in EHP countries. The returns to primary factors fall in other regions.

Trade increases in all of the ACFTA signatory countries. As shown in Table 13.4, total exports and imports increase in China by US\$276 million and US\$297 million respectively, by US\$121 million and US\$83 million in ASEAN +5 and by US\$59 million and US\$49 million in new ASEAN member countries. In aggregate, the EHP increases global exports (or imports) by US\$286 million. Moreover, the exports and imports of the commodities listed in the EHP increase in all ACFTA signatory countries and their growth rates are larger than those of other commodities. 
There are trade diversion effects for non-member regions. This can be seen more clearly in Table 13.5, which shows the changes in bilateral trade flows associated with the EHP. China's exports to ASEAN increase by US\$317 million but its exports to other regions fall by US\$41 million; as a result, China's total exports increase by US\$276 million. China's imports increase by US\$297 million, of which those from ASEAN increase by US\$592 million; but China's imports from other regions decline by US\$296 million. The changes in exports and imports with ASEAN also reflect the importance of China-ASEAN trade. The exports of other regions to China and ASEAN+5 decline by US\$350 million. Although exports from other regions to new ASEAN member countries increase only marginally (by US\$4 million), the total exports of other regions fall by US\$169 million.

In general, the output prices of commodities in ACFTA signatory countries rise because of the increasing cost of production. As the standard GTAP model assumes perfect competition in markets, firms have zero profits and the output price is equal to the production cost. Therefore, the rising prices of primary input factors pull up the output prices. As shown in Table 13.6, prices increase in all the participant countries; however, in China, output prices for processed food, fish, textiles and apparel decline marginally. This is mainly because the tariff reductions lower the import prices of fruits and vegetables, pork and poultry products, which are the

Table 13.3 The macro impacts of the EHP

\begin{tabular}{lcccc}
\hline & & & & \\
& China & Old ASEAN & New ASEAN & Other regions \\
EV (US\$ million) & 13.65 & 56.55 & 25.80 & -77.03 \\
EV/GNP (\%) & 0.001 & 0.012 & 0.021 & 0.000 \\
GDP (\%) & 0.000 & 0.031 & 0.079 & -0.002 \\
GDP price (\%) & -0.001 & 0.030 & 0.078 & -0.002 \\
Price of land (\%) & 0.029 & 0.706 & 1.570 & -0.030 \\
Wages of unskilled labour (\%) & 0.012 & 0.040 & 0.063 & -0.002 \\
Wages of skilled labour (\%) & 0.011 & 0.007 & 0.021 & -0.001 \\
Price of capital (\%) & 0.010 & 0.009 & 0.019 & -0.001 \\
& & & & \\
\hline
\end{tabular}

Note: EV - Equivalent variation

Source: Results of author's simulation. 
Table 13.4 The impact of the EHP on imports and exports

\begin{tabular}{|c|c|c|c|c|c|c|c|c|}
\hline & \multicolumn{4}{|c|}{ Percentage change in exports } & \multicolumn{4}{|c|}{ Percentage change in imports } \\
\hline & China & Old & New & Other & China & Old & New & Other \\
\hline & & ASEAN & ASEAN & regions & & ASEAN & ASEAN & regions \\
\hline Rice & 0.35 & -0.27 & -0.73 & 0.12 & -0.58 & 0.12 & 2.50 & -0.03 \\
\hline Wheat & 0.00 & 0.00 & 0.00 & -0.01 & 0.00 & 0.00 & 0.00 & -0.01 \\
\hline Coarse grain & 0.00 & 0.00 & -4.76 & 0.01 & 0.14 & 0.34 & 0.00 & -0.01 \\
\hline Vegetables and fruits & 4.13 & 3.26 & 11.04 & -0.14 & 10.01 & 2.09 & 16.81 & -0.02 \\
\hline Oil seeds & 0.00 & 0.00 & -1.56 & 0.02 & 0.03 & 0.12 & 0.00 & 0.00 \\
\hline Sugar & 0.00 & 0.00 & 0.00 & 0.03 & 0.00 & 0.15 & 0.00 & 0.00 \\
\hline Cotton & 0.00 & 0.00 & 0.00 & 0.02 & 0.11 & 0.00 & 0.00 & -0.01 \\
\hline Vegetable oil & 0.72 & -0.08 & 0.00 & 0.02 & -0.16 & 0.00 & 0.00 & -0.01 \\
\hline Other crops & 6.65 & 0.92 & 2.03 & -0.23 & 4.38 & 1.49 & 11.36 & -0.04 \\
\hline Cattle and mutton & 1.11 & 3.23 & 0.00 & -0.01 & 0.18 & 0.17 & 0.00 & -0.01 \\
\hline Pork and poultry & 3.01 & 9.50 & 6.45 & -0.42 & 3.76 & 5.38 & 1.11 & -0.02 \\
\hline Milk & 0.00 & 0.97 & 0.00 & -0.01 & 0.41 & 0.06 & 0.30 & -0.01 \\
\hline Fish & 0.16 & 0.31 & 1.33 & -0.03 & 1.14 & 0.00 & 0.00 & -0.01 \\
\hline Processed food & 0.10 & -0.05 & -0.29 & 0.00 & -0.05 & 0.10 & 0.14 & 0.00 \\
\hline Textiles and apparel & 0.03 & -0.02 & -0.16 & -0.01 & -0.01 & -0.01 & 0.00 & 0.00 \\
\hline \multirow[t]{4}{*}{ Other industries } & -0.03 & -0.05 & -0.10 & 0.00 & 0.01 & -0.02 & 0.05 & 0.00 \\
\hline & \multicolumn{4}{|c|}{ Change in exports (US\$ million) } & \multicolumn{4}{|c|}{ Change in imports (US\$ million) } \\
\hline & China & Old & New & Other & China & Old & New & Other \\
\hline & & ASEAN & ASEAN & regions & & ASEAN & ASEAN & regions \\
\hline Rice & 2 & -5 & -5 & 6 & -1 & 1 & 1 & -2 \\
\hline Wheat & 0 & 0 & 0 & -1 & 0 & 0 & 0 & -1 \\
\hline Coarse grain & 0 & 0 & -1 & 1 & 1 & 2 & 0 & -2 \\
\hline Vegetables and fruits & 78 & 51 & 72 & -62 & 99 & 27 & 20 & -7 \\
\hline Oil seeds & 0 & 0 & -1 & 3 & 2 & 1 & 0 & 0 \\
\hline Sugar & 0 & 0 & 0 & 2 & 0 & 1 & 0 & 0 \\
\hline Cotton & 0 & 0 & 0 & 2 & 2 & 0 & 0 & -1 \\
\hline Vegetable oil & 1 & -4 & 0 & 2 & -1 & 0 & 0 & -1 \\
\hline Other crops & 89 & 56 & 16 & -75 & 58 & 32 & 10 & -16 \\
\hline Cattle and mutton & 1 & 2 & 0 & -2 & 1 & 1 & 0 & -2 \\
\hline Pork and poultry & 141 & 206 & 6 & -175 & 118 & 65 & 1 & -8 \\
\hline Milk & 0 & 4 & 0 & -2 & 2 & 1 & 1 & -2 \\
\hline Fish & 1 & 2 & 1 & -2 & 1 & 0 & 0 & -1 \\
\hline Processed food & 7 & -7 & -5 & 6 & -2 & 7 & 2 & -6 \\
\hline Textiles and apparel & 47 & -5 & -12 & -40 & -4 & -1 & 0 & -6 \\
\hline Other industries & -88 & -175 & -13 & 168 & 21 & -56 & 15 & -88 \\
\hline Total & 276 & 121 & 59 & -170 & 297 & 83 & 49 & -143 \\
\hline
\end{tabular}

Source: Results of authors' simulation. 
important intermediate inputs of processed food. Therefore, because the cost reduction on intermediate inputs is dominant, the combined effects of the EHP reduce the production costs of these commodities in China.

The changes in production reflect the combined changes in sectoral exports and imports and domestic consumption resulting from the removal of trade barriers. The driving force underlying such change is the comparative advantage in each region. It is clear that the EHP will shift the primary input factors into the agricultural sectors experiencing tariff reductions. As shown in Table 13.6, all the industrial and other agricultural sectors without tariff reductions will shrink in ASEAN. It is, however, a little different for China. The production of processed food, textiles and apparel expands marginally due to enhanced competitiveness arising from their falling output price.

Increases in the output of the commodities listed in the EHP are not, however, assured. Two factors will determine changes in production: the first is competition from China's trading partners. Taking vegetables and fruits in China, for example, although production will increase by 0.3 per cent due to ASEAN's import tariff reduction, the increasing competition induced by China's tariff reduction will reduce production by 0.4 per cent. Therefore, the total effect on China's production of vegetables and fruits is a decline of 1 per cent. The second factor is competition among sectors for limited resources. If more production factors are drawn into sectors experiencing strong expansion, the production of other sectors could be undermined. Taking the milk sector in China, for example, as ASEAN

Table 13.5 Changes in bilateral trade flows (US\$ million)

\begin{tabular}{lccccc}
\hline & China & Old ASEAN & New ASEAN & Other regions & Exports \\
China & & 266 & 51 & -41 & 276 \\
Old ASEAN & 465 & -118 & -6 & -220 & 121 \\
New ASEAN & 127 & -12 & 0 & -58 & 59 \\
Other regions & -296 & -54 & 4 & 176 & -169 \\
Imports & 297 & 83 & 49 & -143 & \\
& & & & & \\
\hline
\end{tabular}

Source: Results of authors' simulation. 
Table 13.6 Changes in supply price and output by the EHP (per cent)

\begin{tabular}{|c|c|c|c|c|c|}
\hline & \multirow[b]{2}{*}{$\begin{array}{l}\text { Supply } \\
\text { price }\end{array}$} & \multirow[b]{2}{*}{ Output } & \multicolumn{3}{|c|}{ Contribution to output by } \\
\hline & & & $\begin{array}{l}\text { China } \\
\text { Tariff } \\
\text { reduction }\end{array}$ & $\begin{array}{l}\text { Old ASEAN } \\
\text { Tariff } \\
\text { reduction }\end{array}$ & $\begin{array}{c}\text { New ASEAN } \\
\text { Tariff } \\
\text { reduction }\end{array}$ \\
\hline \multicolumn{6}{|l|}{ China } \\
\hline Vegetables and fruits & 0.01 & -0.01 & -0.04 & 0.02 & 0.01 \\
\hline Other crops & 0.28 & 0.74 & -0.82 & 1.29 & 0.27 \\
\hline Cattle and mutton & 0.01 & 0.02 & 0.03 & -0.02 & 0.00 \\
\hline Pork and poultry & 0.01 & 0.01 & -0.07 & 0.08 & 0.00 \\
\hline Milk & 0.00 & -0.03 & 0.00 & -0.02 & -0.01 \\
\hline Fish & -0.01 & 0.01 & 0.00 & 0.01 & 0.00 \\
\hline Processed food & -0.04 & 0.03 & 0.03 & 0.00 & 0.00 \\
\hline Textiles and apparel & -0.01 & 0.03 & 0.06 & -0.03 & -0.01 \\
\hline Other agricultural products & 0.01 & 0.02 & 0.01 & 0.01 & 0.00 \\
\hline Other industries & 0.00 & -0.01 & 0.00 & -0.01 & 0.00 \\
\hline \multicolumn{6}{|l|}{ Old ASEAN } \\
\hline Vegetables and fruits & 0.31 & 0.11 & 0.25 & -0.11 & -0.03 \\
\hline Other crops & 0.30 & 0.09 & 0.18 & -0.09 & 0.00 \\
\hline Cattle and mutton & 0.04 & 0.02 & -0.01 & 0.03 & 0.00 \\
\hline Pork and poultry & 0.26 & 0.82 & 1.16 & -0.34 & 0.01 \\
\hline Milk & 0.05 & 0.23 & 0.16 & 0.07 & 0.00 \\
\hline Fish & 0.01 & 0.02 & 0.02 & 0.00 & 0.00 \\
\hline Processed food & 0.04 & -0.01 & -0.05 & 0.04 & 0.00 \\
\hline Textiles and apparel & 0.00 & -0.01 & -0.11 & 0.10 & 0.00 \\
\hline Other agricultural products & 0.11 & -0.04 & -0.07 & 0.03 & 0.00 \\
\hline Other industries & 0.01 & -0.03 & -0.03 & 0.01 & 0.00 \\
\hline \multicolumn{6}{|l|}{ New ASEAN } \\
\hline Vegetables and fruits & 1.37 & 1.04 & 1.32 & -0.01 & -0.27 \\
\hline Other crops & 0.52 & 0.04 & 0.09 & -0.01 & -0.05 \\
\hline Cattle and mutton & 0.17 & -0.07 & -0.09 & 0.00 & 0.02 \\
\hline Pork and poultry & 0.27 & 0.11 & 0.11 & -0.04 & 0.04 \\
\hline Milk & 0.10 & -0.08 & -0.11 & 0.00 & 0.04 \\
\hline Fish & 0.01 & 0.01 & 0.00 & 0.00 & 0.01 \\
\hline Processed food & 0.12 & -0.10 & -0.13 & -0.01 & 0.04 \\
\hline Textiles and apparel & 0.02 & -0.10 & -0.15 & 0.01 & 0.03 \\
\hline Other agricultural products & 0.29 & -0.15 & -0.18 & -0.01 & 0.04 \\
\hline Other industries & 0.03 & -0.02 & -0.03 & 0.00 & 0.00 \\
\hline
\end{tabular}

Source: Results of authors' simulation. 
tariff reductions will promote production in some sectors quite strongly, production factors will be drawn away from the milk sector; as a result, the production of milk will fall by 0.03 per cent due to the relocation of production factors.

The economic impacts of the full implementation of the ACFTA

The macro effects of the full implementation of the ACFTA are much larger than those of the EHP. The increases in real GDP and social welfare in the ACFTA signatories are much larger than those in the EHP (Table 13.7). Welfare in all ACFTA signatories increases by US\$1.8 billion, with US\$451 million in China, US\$1.25 billion in ASEAN+5 and US\$92 million in the new ASEAN members. ASEAN +5 is the largest beneficiary in absolute and relative terms. The negative impacts on the rest of the world are also more significant than those of the EHP. The social welfare of other regions declines by US\$1.9 billion. The global welfare loss due to the creation of the ASEAN-China Free Trade Area is US\$115 million.

The impacts on the returns to primary factors in ACFTA signatories are substantial. As shown in Table 13.7, all the returns to primary factors increase in China and in the new ASEAN members. As for ASEAN +5 , returns to labour and capital increase while returns to land decline. Land is the sluggish factor in the GTAP model, so its price can vary across sectors (Hertel 1997). The land prices reported in Table 13.7 reflect the aggregate effects of policy changes on land use. Because the non-agricultural sectors in ASEAN+5 grow so strongly and draw labour and capital away from agricultural sectors, the demand for land declines. As a result, land prices drop after the full implementation of the ACFTA. The returns to primary factors in the other regions decline marginally.

The results indicate that there will be trade gains for all ACFTA signatories. Trade creation will easily offset trade diversion. As shown in Tables 13.8 and 13.9, total exports and imports increase by US\$6.5 billion and US\$6.8 billion, respectively, for China, by US\$4.7 billion and US\$4.9 billion for ASEAN+5 and by US\$153 million and US\$203 million for the new ASEAN members. As a whole, the implementation of the ACFTA by 2010 will promote global exports of US\$8.2 billion.

The effects on exports and imports vary remarkably across sectors. While 
there are declines in cattle and mutton, pork and poultry, manufacturing and services, exports of other commodities from China increase. As shown in Table 13.8, the most significant growth in absolute terms is in electronic products in the industrial sector and in processed food in the agricultural sector. Although the growth of sugar in China is very impressive, its increase in absolute terms is limited as its initial export value is very small. As for ASEAN+5 and the new ASEAN members, exports of natural resourcerelated industrial products in the industrial sector and vegetable oils in the agricultural sector increase most significantly in absolute terms. The growth in the export of sugar is also quite remarkable-in ASEAN +5 and in the new ASEAN members.

Imports also rise among the ACFTA signatories. China's imports of sugar and vegetable oil rise significantly, increasing by 10.5 per cent (US\$40 million) and 28.5 per cent (US\$174 million) respectively. As China does not have comparative advantage in these two agricultural commodities, its imports of vegetable oils (mainly palm oil) from ASEAN have risen dramatically in recent years. The elimination of import tariffs will further stimulate the importation of vegetable oil from ASEAN. China's imports of natural resource-related industrial products, electronics and metal and machinery also increase significantly. The increase in these three commodities accounts for 85.5 per

Table 13.7 The macro effects of the implementation of the ACFTA, up to 2010

\begin{tabular}{lcccc}
\hline & & & & \\
& China & Old ASEAN & New ASEAN & Other regions \\
EV (US\$ million) & 451 & 1,254 & 92 & $-1,912$ \\
EV/GNP (\%) & 0.025 & 0.244 & 0.062 & -0.006 \\
GDP (\%) & 0.141 & 0.610 & 0.351 & 0.034 \\
GDP price (\%) & 0.136 & 0.576 & 0.338 & -0.033 \\
Price of land (\%) & 0.200 & -0.071 & 0.156 & 0.001 \\
Wages of unskilled labour (\%) & 0.288 & 0.877 & 0.310 & -0.002 \\
Wages of skilled labour (\%) & 0.311 & 0.848 & 0.317 & -0.001 \\
Price of capital (\%) & 0.306 & 0.889 & 0.333 & -0.001 \\
& & & & \\
\hline
\end{tabular}

Note: EV - Equivalent variation

Source: Results of authors' simulation. 
cent of the total increase in imports of industrial products.

For ASEAN+5, among agricultural products, imports of processed food increase most significantly (by 2.83 per cent or US\$212 million). Imports of all industrial products increase, with the highest growth rate of 6.75 per cent (US\$683 million) in textiles and apparel, and the largest increase in value of US\$1.05 billion in metal and machinery (a 1.98 per cent increase). Because the new ASEAN members will continue to implement the tariff reduction

Table 13.8 Impacts on exports after implementation of the ACFTA, up to 2010

\begin{tabular}{|c|c|c|c|c|c|c|c|c|}
\hline & \multicolumn{4}{|c|}{ Change in exports (US\$ million) } & \multicolumn{4}{|c|}{ Percentage change in exports } \\
\hline & China & $\begin{array}{c}\text { Old } \\
\text { ASEAN }\end{array}$ & $\begin{array}{c}\mathrm{New} \\
\text { ASEAN }\end{array}$ & $\begin{array}{c}\text { Other } \\
\text { regions }\end{array}$ & China & $\begin{array}{c}\text { Old } \\
\text { ASEAN }\end{array}$ & $\begin{array}{c}\text { New } \\
\text { ASEAN }\end{array}$ & $\begin{array}{l}\text { Other } \\
\text { regions }\end{array}$ \\
\hline Rice & 6 & -14 & 3 & 21 & 1.15 & -0.77 & 0.40 & 0.42 \\
\hline Wheat & 2 & 0 & 0 & -9 & 6.61 & -0.70 & 1.24 & -0.06 \\
\hline Coarse grain & 2 & 0 & 0 & 3 & 0.49 & -0.33 & -0.23 & 0.02 \\
\hline Vegetables and fruits & 6 & -13 & 0 & 19 & 0.34 & -0.73 & -0.04 & 0.04 \\
\hline Oil seeds & 8 & -1 & 0 & -18 & 2.68 & -0.90 & -0.57 & -0.09 \\
\hline Sugar & 12 & 81 & 3 & -43 & 64.51 & 12.33 & 11.55 & -0.55 \\
\hline Cotton & 2 & 2 & 2 & -4 & 0.84 & 2.92 & 14.34 & -0.03 \\
\hline Vegetable oil & 4 & 102 & 18 & 51 & 2.43 & 2.29 & 83.90 & 0.45 \\
\hline Other crops & 3 & -34 & 1 & 34 & 0.25 & -0.55 & 0.07 & 0.10 \\
\hline Cattle and mutton & -1 & -2 & 0 & 3 & -0.75 & -2.75 & 0.04 & 0.01 \\
\hline Pork and poultry & -37 & -43 & -1 & 85 & -0.70 & -2.03 & -0.81 & 0.20 \\
\hline Milk & 0 & -8 & 0 & 9 & 0.77 & -1.57 & -1.02 & 0.03 \\
\hline Fish & 0 & 0 & 0 & 4 & 0.06 & 0.01 & -0.06 & 0.06 \\
\hline Processed food & 474 & -22 & 8 & -193 & 6.21 & -0.16 & 0.46 & -0.11 \\
\hline Natural resources & 48 & -273 & -11 & 696 & 2.63 & -1.45 & -0.19 & 0.20 \\
\hline Textiles and apparel & 642 & 478 & -59 & -84 & 0.38 & 2.14 & -0.71 & -0.03 \\
\hline Natural industry & 708 & 2,736 & 200 & $-1,297$ & 1.18 & 4.59 & 9.50 & -0.12 \\
\hline Metal and machinery & 1,489 & 1,522 & -16 & $-1,198$ & 1.27 & 2.79 & -0.90 & -0.09 \\
\hline Transportation & 550 & 9 & -3 & -362 & 3.91 & 0.11 & -1.38 & -0.05 \\
\hline Electronics & 2,723 & 1,309 & 33 & $-2,429$ & 2.06 & 0.75 & 5.93 & -0.42 \\
\hline Manufactures & -48 & 28 & 4 & 135 & -0.08 & 0.35 & 0.64 & 0.10 \\
\hline Services & -132 & -1142 & -28 & 1,462 & -0.52 & -1.74 & -0.80 & 0.11 \\
\hline Total & 6,463 & 4,717 & 153 & $-3,115$ & 1.08 & 1.06 & 0.56 & -0.05 \\
\hline
\end{tabular}

Source: Results of authors' simulation. 
schedule for the commodities listed in the EHP during 2006-10, imports of these agricultural commodities increase more than imports of other commodities. As there is no liberalisation in industrial sectors, the import growth of industrial products in the new ASEAN members is very small.

There is significant trade diversion from the non-member regions during the full implementation of the ACFTA. China's exports to ASEAN +5 and the new ASEAN members increase by 35.6 per cent (US\$8.8 billion) and 0.9 per

Table 13.9 Impacts on imports of the implementation of the ACFTA, up to 2010

\begin{tabular}{|c|c|c|c|c|c|c|c|c|}
\hline & \multicolumn{4}{|c|}{ Change in imports (US\$ million) } & \multicolumn{4}{|c|}{ Percentage change in imports } \\
\hline & China & $\begin{array}{c}\text { Old } \\
\text { ASEAN }\end{array}$ & $\begin{array}{c}\text { New } \\
\text { ASEAN }\end{array}$ & $\begin{array}{l}\text { Other } \\
\text { regions }\end{array}$ & China & $\begin{array}{c}\text { Old } \\
\text { ASEAN }\end{array}$ & $\begin{array}{c}\text { New } \\
\text { ASEAN }\end{array}$ & $\begin{array}{l}\text { Other } \\
\text { regions }\end{array}$ \\
\hline Rice & 7 & 16 & 0 & -7 & 3.26 & 1.54 & 0.44 & -0.09 \\
\hline Wheat & 2 & -8 & 0 & -2 & 0.45 & -0.61 & 0.02 & -0.01 \\
\hline Coarse grain & 2 & 2 & 0 & 0 & 0.28 & 0.36 & 0.27 & 0.00 \\
\hline Vegetables and fruits & 4 & 8 & 7 & -9 & 0.31 & 0.60 & 4.45 & -0.02 \\
\hline Oil seeds & -21 & 8 & 0 & 3 & -0.28 & 0.89 & 1.07 & 0.02 \\
\hline Sugar & 40 & 15 & 0 & -2 & 10.52 & 2.17 & 0.33 & -0.02 \\
\hline Cotton & 6 & -4 & 0 & -1 & 0.32 & -0.34 & 0.41 & -0.01 \\
\hline Vegetable oil & 174 & 10 & 1 & -10 & 28.45 & 1.93 & 0.53 & -0.06 \\
\hline Other crops & 3 & 5 & 8 & -12 & 0.18 & 0.21 & 6.75 & -0.03 \\
\hline Cattle and mutton & 2 & 7 & 0 & -9 & 0.42 & 1.17 & 1.04 & -0.03 \\
\hline Pork and poultry & 16 & 13 & 3 & -26 & 0.41 & 0.93 & 2.55 & -0.06 \\
\hline Milk & 2 & 6 & 1 & -8 & 0.35 & 0.32 & 0.40 & -0.03 \\
\hline Fish & 0 & 1 & 0 & 3 & 0.10 & 0.30 & 1.54 & 0.04 \\
\hline Processed food & 116 & 212 & 6 & -67 & 2.25 & 2.83 & 0.28 & -0.04 \\
\hline Natural resources & 40 & 356 & 1 & 63 & 0.15 & 2.27 & 1.01 & 0.02 \\
\hline Textiles and apparel & 601 & 683 & 8 & -314 & 1.81 & 6.75 & 0.27 & -0.07 \\
\hline Natural industry & 1,978 & 785 & 36 & -452 & 3.08 & 1.76 & 0.53 & -0.04 \\
\hline Metal and machinery & 1,641 & 1,048 & 26 & -919 & 1.90 & 1.35 & 0.38 & -0.07 \\
\hline Transportation & 179 & 264 & 11 & -260 & 0.98 & 1.39 & 0.45 & -0.04 \\
\hline Electronics & 1,691 & 699 & 13 & -766 & 2.20 & 0.68 & 0.78 & -0.11 \\
\hline Manufactures & 123 & 155 & 3 & -161 & 3.53 & 3.00 & 0.65 & -0.08 \\
\hline Services & 238 & 662 & 79 & -819 & 0.36 & 1.15 & 0.56 & -0.06 \\
\hline Total & 6,845 & 4,944 & 203 & $-3,773$ & 1.71 & 1.40 & 0.52 & -0.06 \\
\hline
\end{tabular}

Source: Results of authors' simulation. 
cent (US\$44 million), respectively (Table 13.10). In contrast, China's exports to other regions decline by 0.4 per cent (US\$2.4 billion). The same pattern occurs in ASEAN +5 and the new ASEAN countries, even with the reduction in trade among ASEAN members. As for the other regions, exports to China and ASEAN +5 fall by 0.9 per cent (US\$5.2 billion) and by 0.5 per cent (US\$1.6 billion), respectively. Exports to the new ASEAN members, however, and to the other regions (individually) rise by 1 per cent (US\$201 million) and 0.1 per cent (US\$3.5 billion) respectively. Overall, exports of the rest of the world decline by 0.1 per cent (US\$3.1 billion).

Table 13.11 shows the changes in supply prices and output in China. Except for sugar, vegetable oil and electronics, supply prices rise due to the increasing costs of the primary factors. Because land is the sluggish factor, land rents in the sugar and vegetable oil sectors in China fall because of the dramatic decline in the production and prices of sugar and vegetable oil caused by the large imports of these commodities from ASEAN. The price decline in electronics is caused by the cost reduction of the intermediate inputs more than offsetting the increases in prices of the primary factors. The elimination of import tariffs will reduce the

Table 13.10 Changes in bilateral trade after the implementation of the ACFTA, up to 2010

\begin{tabular}{|c|c|c|c|c|c|}
\hline & China & ASEAN +5 & New ASEAN & Other regions & Exports \\
\hline \multicolumn{6}{|c|}{ Value (US\$ million, in world prices) } \\
\hline China & 0 & 8,800 & 44 & $-2,380$ & 6,463 \\
\hline Old ASEAN & 11,539 & $-2,147$ & -42 & $-4,632$ & 4,717 \\
\hline New ASEAN & 465 & -97 & 0 & -215 & 153 \\
\hline Other regions & $-5,159$ & $-1,611$ & 201 & 3,454 & $-3,115$ \\
\hline Imports & 6,845 & 4,944 & 203 & $-3,773$ & \\
\hline \multicolumn{6}{|l|}{ Percentage } \\
\hline China & & 35.6 & 0.9 & -0.4 & 1.1 \\
\hline Old ASEAN & 41.4 & -2.7 & -1.0 & -1.7 & 1.4 \\
\hline New ASEAN & 9.6 & -1.0 & 0 & 0.8 & 0.4 \\
\hline Other regions & -0.9 & -0.5 & 1 & 0.1 & -0.1 \\
\hline Imports & 1.7 & 1.4 & 0.5 & -0.1 & \\
\hline
\end{tabular}

Source: Results of authors' simulation. 
import prices of finished and semi-finished products of electronics from ASEAN. Imported semi-finished electronic products account for a significant share of the total production cost of electronics. As a result, the prices of electronics in China fall.

In China, the ACFTA will promote the production and increase the output of rice, vegetables and fruits, processed foods and fish in the agricultural sector and metal and machinery, transportation and electronics in the industrial sector (Table 13.11). In order to distinguish between the effects of trade liberalisation on output in agriculture and industry, we further decompose the total impacts on output into three sources: the contribution of tariff reductions on agricultural commodities listed in the EHP for the new ASEAN members; the contribution of tariff reductions on other agricultural commodities; and the contribution of tariff reductions on industrial products.

The decomposition of the total impacts on output reveals the direct effect of trade liberalisation and the effect of resource relocation. Taking the processed-food sector in China, for example, the tariff reduction in the agricultural sector increases its production by 0.26 per cent, but the liberalisation of industry draws resources out of the agricultural sector and reduces processed-food production by 0.03 per cent. The combined impact is to increase processed-food production by 0.24 per cent. As vegetables and fruits are the most important intermediate inputs of the processed-food industry, the increase in output of the processed-food sector promotes the production of vegetables and fruits. ${ }^{11}$

China's huge domestic market will provide great opportunities for ASEAN countries, but the effects on output will be determined by their comparative advantages and by competition among sectors. As Table 13.12 shows, the supply prices of all commodities in ASEAN +5 rise; however, this is not the case for output. In agricultural sectors, the output of sugar and vegetable oil increases but other agricultural sectors shrink. In the industrial sector, the output of natural resource-related industry, electronics and metal and machinery increases but the others decline. The full implementation of the ACFTA should, therefore, help ASEAN+5 members to exploit their comparative advantages.

According to the ACFTA, the new ASEAN members will have a transitional 
period beyond 2010 to eliminate most import tariffs, but they will continue to reduce the tariff lines on commodities listed in the EHP until 2010. For commodities not listed in the EHP, the new ASEAN members will enjoy the opportunities of reduced tariffs in China's market without any liberalisation on their part before 2010. As shown in Table 13.13, the tariff reductions on the commodities in the EHP reduce the production of those agricultural commodities, except for fish, in the new ASEAN members.

Table 13.11 Changes in China in supply prices and output from the implementation of the ACFTA, up to 2010

\begin{tabular}{|c|c|c|c|c|c|}
\hline & & & Cont & ibution to outp & it by \\
\hline & $\begin{array}{l}\text { Supply } \\
\text { price }\end{array}$ & Output & $\begin{array}{l}\text { Tariff } \\
\text { reductions } \\
\text { from EHP }\end{array}$ & $\begin{array}{c}\text { Tariff } \\
\text { reductions } \\
\text { in agriculture }\end{array}$ & $\begin{array}{c}\text { Tariff } \\
\text { reductions } \\
\text { in industry }\end{array}$ \\
\hline Rice & 0.216 & 0.002 & 0.000 & 0.023 & -0.021 \\
\hline Wheat & 0.160 & -0.026 & 0.000 & 0.042 & -0.068 \\
\hline Coarse grain & 0.166 & -0.058 & 0.000 & 0.009 & -0.068 \\
\hline Vegetables and fruits & 0.240 & 0.032 & 0.003 & 0.058 & -0.029 \\
\hline Oil seeds & 0.109 & -0.332 & -0.002 & -0.203 & -0.127 \\
\hline Sugar & -0.139 & -1.778 & -0.002 & -1.710 & -0.067 \\
\hline Cotton & 0.105 & -0.173 & -0.004 & -0.030 & -0.139 \\
\hline Vegetable oil & -0.039 & -2.968 & -0.001 & -3.107 & 0.140 \\
\hline Other crops & 0.205 & -0.099 & 0.198 & -0.051 & -0.246 \\
\hline Cattle and mutton & 0.190 & -0.126 & -0.001 & -0.010 & -0.115 \\
\hline Pork and poultry & 0.200 & -0.074 & 0.001 & -0.013 & -0.062 \\
\hline Milk & 0.179 & -0.133 & 0.011 & -0.003 & -0.141 \\
\hline Fish & 0.080 & 0.009 & 0.001 & -0.013 & 0.021 \\
\hline Processed food & 0.171 & 0.236 & -0.001 & 0.262 & -0.025 \\
\hline Natural resources & 0.086 & -0.121 & -0.001 & -0.005 & -0.115 \\
\hline Textiles and apparel & 0.152 & -0.113 & -0.003 & -0.021 & -0.090 \\
\hline Natural industry & 0.117 & -0.262 & -0.001 & -0.007 & -0.255 \\
\hline Metal and machinery & 0.129 & 0.017 & -0.001 & -0.015 & 0.033 \\
\hline Transportation & 0.138 & 0.473 & -0.001 & -0.009 & 0.482 \\
\hline Electronics & -0.097 & 0.912 & -0.001 & -0.022 & 0.935 \\
\hline Manufactures & 0.162 & -0.219 & -0.001 & -0.019 & -0.198 \\
\hline Services & 0.193 & 0.022 & 0.000 & -0.001 & 0.023 \\
\hline
\end{tabular}

Source: Results of authors' simulation. 
The output of vegetable oil, sugar, cotton, processed food, oil seeds and rice is, however, expected to increase. In the industrial sector, the output of natural resource-related industry, electronics, and manufactures will increase, but others will shrink.

Table 13.12 Changes in ASEAN+5 in supply prices and output after the implementation of the ACFTA, up to 2010

\begin{tabular}{|c|c|c|c|c|c|}
\hline & \multirow[b]{2}{*}{$\begin{array}{l}\text { Supply } \\
\text { price }\end{array}$} & \multirow[b]{2}{*}{ Output } & \multicolumn{3}{|c|}{ Contribution to output by } \\
\hline & & & $\begin{array}{l}\text { Tariff } \\
\text { reductions } \\
\text { from EHP }\end{array}$ & $\begin{array}{c}\text { Tariff } \\
\text { reductions } \\
\text { in agriculture }\end{array}$ & $\begin{array}{l}\text { Tariff } \\
\text { reductions } \\
\text { in industry }\end{array}$ \\
\hline Rice & 0.514 & -0.250 & -0.002 & -0.013 & -0.235 \\
\hline Wheat & 0.054 & -0.689 & 0.009 & -0.086 & -0.612 \\
\hline Coarse grain & 0.222 & -0.473 & 0.002 & -0.126 & -0.348 \\
\hline Vegetables and fruits & 0.464 & -0.027 & -0.011 & -0.028 & 0.011 \\
\hline Oil seeds & 0.384 & -0.133 & 0.004 & 0.222 & -0.358 \\
\hline Sugar & 0.784 & 1.037 & 0.001 & 1.470 & -0.434 \\
\hline Cotton & 0.232 & -0.405 & 0.007 & 0.209 & -0.621 \\
\hline Vegetable oil & 0.674 & 0.875 & 0.000 & 2.177 & -1.303 \\
\hline Other crops & 0.198 & -0.428 & -0.001 & -0.069 & -0.358 \\
\hline Cattle and mutton & 0.536 & -0.199 & 0.001 & 0.016 & -0.216 \\
\hline Pork and poultry & 0.468 & -0.237 & -0.004 & 0.055 & -0.288 \\
\hline Milk & 0.340 & -1.134 & -0.009 & 0.212 & -1.337 \\
\hline Fish & 0.191 & -0.094 & 0.000 & -0.047 & -0.047 \\
\hline Processed food & 0.387 & -0.647 & 0.001 & -0.207 & -0.440 \\
\hline Natural resources & 0.296 & -0.396 & 0.000 & -0.014 & -0.382 \\
\hline Textiles and apparel & 0.112 & -0.666 & 0.002 & -0.064 & -0.603 \\
\hline Natural industry & 0.361 & 1.670 & 0.001 & -0.038 & 1.707 \\
\hline Metal and machinery & 0.213 & 1.287 & 0.001 & -0.080 & 1.366 \\
\hline Transportation & 0.268 & -0.678 & 0.000 & -0.031 & -0.647 \\
\hline Electronics & 0.158 & 0.488 & 0.001 & -0.090 & 0.577 \\
\hline Manufactures & 0.254 & -0.728 & 0.000 & -0.060 & -0.669 \\
\hline Services & 0.638 & -0.225 & 0.000 & -0.010 & -0.215 \\
\hline
\end{tabular}

Source: Results of authors' simulation. 


\section{Conclusions}

This chapter assesses the economic effects of the ACFTA in its two stages up to 2010. The analysis is based on an improved recursive GTAP model. The data are based on Version 6 of the GTAP database for 2001, together with data derived from other sources. There are two distinguishing characteristics of this study. The first is that, in addition to the commitments in the ACFTA, the study incorporates trade liberalisation in China (China's

Table 13.13 Changes in the new ASEAN members in supply prices and output after the implementation of the ACFTA, up to 2010

\begin{tabular}{|c|c|c|c|c|c|}
\hline & \multirow[b]{2}{*}{$\begin{array}{c}\text { Supply } \\
\text { price }\end{array}$} & \multirow[b]{2}{*}{ Output } & \multicolumn{3}{|c|}{ Contribution to output by } \\
\hline & & & $\begin{array}{l}\text { Tariff } \\
\text { reductions } \\
\text { from EHP }\end{array}$ & $\begin{array}{c}\text { Tariff } \\
\text { reductions } \\
\text { in agriculture }\end{array}$ & $\begin{array}{l}\text { Tariff } \\
\text { reductions } \\
\text { in industry }\end{array}$ \\
\hline Rice & 0.274 & 0.054 & 0.018 & -0.010 & 0.046 \\
\hline Wheat & 0.221 & -0.030 & 0.386 & -0.074 & -0.342 \\
\hline Coarse grain & 0.225 & -0.023 & 0.024 & 0.040 & -0.087 \\
\hline Vegetables and fruits & 0.168 & -0.072 & -0.066 & -0.003 & -0.003 \\
\hline Oil seeds & 0.300 & 0.091 & 0.052 & 0.107 & -0.068 \\
\hline Sugar & 0.365 & 0.394 & 0.007 & 0.364 & 0.023 \\
\hline Cotton & 0.693 & 0.676 & 0.046 & 0.989 & -0.359 \\
\hline Vegetable oil & 0.307 & 3.560 & 0.005 & 3.264 & 0.291 \\
\hline Other crops & 0.036 & -0.275 & -0.083 & -0.039 & -0.153 \\
\hline Cattle and mutton & 0.271 & -0.030 & 0.003 & -0.008 & -0.024 \\
\hline Pork and poultry & 0.242 & -0.022 & -0.030 & -0.002 & 0.010 \\
\hline Milk & 0.233 & -0.319 & -0.012 & -0.069 & -0.238 \\
\hline Fish & 0.279 & 0.048 & -0.001 & 0.035 & 0.014 \\
\hline Processed food & 0.262 & 0.073 & 0.016 & 0.139 & -0.082 \\
\hline Natural resources & 0.222 & -0.063 & 0.000 & -0.035 & -0.029 \\
\hline Textiles and apparel & 0.234 & -0.595 & 0.021 & -0.094 & -0.521 \\
\hline Natural industry & 0.250 & 1.019 & 0.012 & -0.031 & 1.038 \\
\hline Metal and machinery & 0.255 & -0.537 & 0.001 & -0.067 & -0.472 \\
\hline Transportation & 0.281 & -0.130 & 0.000 & -0.014 & -0.116 \\
\hline Electronics & 0.249 & 0.541 & 0.001 & -0.043 & 0.584 \\
\hline Manufactures & 0.245 & 0.002 & 0.030 & -0.032 & 0.004 \\
\hline Services & 0.294 & -0.015 & 0.000 & -0.002 & -0.013 \\
\hline
\end{tabular}

Source: Results of authors' simulation. 
WTO commitments) and trade liberalisation in ASEAN (ASEAN free trade commitments). The second is that we have separated and explored the different effects of the two-stage implementation of the ACFTA. The following are the key findings of the study.

All member countries will gain from the ACFTA: it will increase social welfare and promote real GDP in the EHP phase from 2004-06 and in the fuller implementation during 2006-10. As the EHP includes only a small package of agricultural commodities, the gains during the fuller implementation of the ACFTA will be much larger in all member countries.

There is a large trade creation effect among the ACFTA signatories; their total exports will increase. A trade diversion effect is, however, also apparent. Trade between ACFTA signatories and other regions can be expected to decline due to the creation of the agreement. Because the trade creation effect is much larger than the trade diversion effect, global trade will be increased by the ACFTA, especially in the fuller implementation stage of the agreement.

The ACFTA will bring about substantial structural changes in China and in ASEAN countries. Trade liberalisation will improve the exploitation of comparative advantages in ACFTA signatories. The structural changes will take place in the agricultural and industrial sectors. Our results also show that the different policy arrangements stemming from the two-stage trade liberalisation will have different impacts on the shifts in economic structure during the process of implementation.

The rest of the world will have to face the challenges brought about by the ACFTA. Because the agreement will enhance the competitiveness of China and ASEAN in each other's markets, exports from non-member countries will be substituted. Social welfare and real GDP will decline in the non-member countries as a result of the creation of the ACFTA.

The results provide some useful insights into the impacts of the ACFTA on trade and economic relations between China and ASEAN; however, some limitations of the exercise should be mentioned. First, as many studies have observed, there are serious disguised unemployment problems in agricultural sectors. This reality is not modelled. Therefore, instead of the increases in wages the ACFTA gives rise to in the simulations, it is more likely that the ACFTA will create job opportunities. If we take this factor into account, China's gain from the agreement could be much larger and the 
changes in sectoral output could be different to the results of this study. Second, because of the lack of information about the barriers to trade in services, this study does not capture the impact of liberalisation in the services sectors. Finally, no allowance has been made for possible increases in capital formation and improvements in productivity that the ACFTA could engender. It is possible that the dynamic growth and productivity gains of the ACFTA could turn out to be very significant.

\section{Notes}

1 The ACFTA will be established in 2010 for ASEAN+6 and China; it will include the newer ASEAN member states of Cambodia, Laos, Myanmar and Vietnam after 2015.

2 This schedule holds for China, Brunei, Singapore, Thailand, Malaysia and Indonesia. Cambodia, Vietnam, Myanmar and Laos will complete their EHP in 2010. The Philippines has not concluded its negotiations.

3 A more complete description of the terms of China's WTO accession is available from http://www.wto.org/english/news_e/pres01_e/pr243_e.htm

4 In this study, all import tariffs-by commodity and country-are calculated by this method.

5 Despite its status as a developing country, China's de minimis exemption for product-specific support is only 8.5 per cent of the value of production of each agricultural product. In comparison, a 10 per cent rate has been agreed with other developing countries.

6 These products include rice, wheat, maize, edible oils, sugar, cotton and wool.

7 The full name for the amending protocol is the Protocol to Amend the Agreement on the Common Effective Preferential Tariff (CEPT) Scheme for the ASEAN Free Trade Area (AFTA) for the Elimination of Import Duties. The agreement can be downloaded from http://www.aseansec.org/14183.htm

8 Member states-except Cambodia, Laos, Myanmar and Vietnam-will eliminate all other non-tariff barriers on sensitive and highly sensitive products by 1 January 2010. Vietnam will eliminate all other non-tariff barriers on sensitive products by 1 January 2013, Laos and Myanmar by 1 January 2015 and Cambodia by 1 January 2017.

9 The deadlines for eliminating tariffs on commodities listed in the EHP vary among the newer ASEAN members: Vietnam before 1 January 2008; Laos and Myanmar before 1 January 2009; and Cambodia before 1 January 2010.

10 We focus mainly on the effects of the ACFTA on China and ASEAN countries. For other countries, we present only the total effects on the rest of the world (other regions).

11 As the GTAP model adopts the Leontief technology, an output increase in a sector promotes its demand for intermediate inputs by the same proportion.

12 As the GTAP Version 6 database has no detailed information on Brunei, only the other five members are included as representative of the original ASEAN members. 


\section{References}

Anderson, K., Huang, J. and lanchovichina, E., 2004. 'Will China's WTO accession worsen farm household income?', China Economic Review, 15:443-56.

ASEAN Joint Experts Group, 2001. Forging closer ASEAN-China economic relations in the 21st century, Report submitted by the ASEAN-China Expert Group on Economic Cooperation, October. Available from http:// www.aseansec.org/newdata/asean_chi.pdf.

ASEAN-China FTA Framework Agreement, 2002. Available online at http:// www.bilaterals.org/article.php3?id_article $=2488$.

ASEAN Secretariat, 2002. Southeast Asia: a free trade area. Available from http://www.aseansec.org/viewpdf.asp?file=/pdf/afta.pdf.

Bhattasali, D., Li., S. and Martin, W. (eds), 2004. China and the WTO: accession, policy reform, and poverty reduction strategies, The World Bank and Oxford University Press, Washington, DC.

Chirathivat, S., 2002. 'ASEAN-China Free Trade Area: background, implications and future development', Journal of Asian Economics, 13(5):671-86.

Ethier, W., 2000. 'The new regionalism', Economic Journal, 108:1,149-61. Fan, S., Wales, E.J. and Crame, G.L., 1995. 'Household demand in rural China: a two-stage LES-AIDS model', American Journal of Agricultural Economics, 77:54-62.

Francois, J.F. and D. Spinanger, 2004. 'WTO accession and the structure of China's motor vehicle sector', in D. Bhattasali, S. Li and W. Martin (eds), China and the WTO: accession, policy reform, and poverty reduction strategies, The World Bank and Oxford University Press, Washington, DC.

Fukase, E. and Winters, L.A., 2003. 'Possible dynamic effects of AFTA for the new member countries', World Economy, 26:853-71.

Hertel, T.W. (ed.), 1997. Global Trade Analysis: modelling and applications, Cambridge University Press.

Hertel, T.W. and Martin, W., 1999. Would developing countries gain from inclusion of manufactures in the WTO negotiations?, GTAP Working Paper, Purdue University, West Lafayette. 
Holst, D. and Weiss, J., 2004. 'ASEAN and China: export rivals or partners in regional growth?', The World Economy, 27(8):1,255-74.

Huang, J. and Bouis, H., 1996. Structural changes in demand for food in Asia, Food, Agriculture and the Environment Discussion Paper, International Food Policy Research Institute, Washington, DC.

Huang, J. and Rozelle, S., 1996. 'Technological change: rediscovery of the engine of productivity growth in China's rural economy', Journal of Development Economics, 49(2):337-69.

--, 1998. 'Market development and food consumption in rural China', China Economic Review, 9:25-45.

Huang, J. and Yang, J., 2006. 'China's rapid economic growth and its implications for agriculture and food security in China and the rest of world', Management World, 1:67-76.

Huang, J., Rozelle, S. and Chang, M., 2004. 'Tracking distortions in agriculture: China and its accession to the World Trade Organization', World Bank Economic Review, 18(1):59-84.

lanchovichina, E. and Martin, W., 2004. 'Economic impacts of China's accession to WTO', in D. Bhattasali, S. Li. and W. Martin (eds), China and the WTO: accession, policy reform, and poverty reduction strategies, The World Bank and Oxford University Press, Washington, DC.

Liu, J., Surry, Y., Dimmaraman, B. and Hertal, T., 1998. 'CDE calibration', in R.A. McDougall, A. Elbehri and T.P. Truoung (eds), Global Trade Assistance and Protection: the GTAP 4 Data Base, Centre for Global Trade Analysis, Purdue University, West Lafayette.

Shang, G., 2005. The Trial Field of China-ASEAN Free Trade Area: early harvest. Available from http://big5.mofcom.gov.cn/gate/big5/www. mofcom.gov.cn/aarticle/Nocategory/200507/20050700180151.html

Tongzon, J., 2005. 'ASEAN-China Free Trade Area: a bane or boon for ASEAN countries?', World Economy, 28(2):191-210.

Tongeren, F. and Huang, J., 2004. China's food economy in the early 21st century, Report, No.6.04.04, Agricultural Economics Research Institute (LEI), The Hague.

United Nations Statistics Division, Commodity Trade Statistics Database, COMTRADE. Available online at http://unstats.un.org/unsd/comtrade/ default.aspx. 
Voon, J. and Yue, R., 2003. 'China-ASEAN export rivalry in the US market: the importance of the HK-China production synergy and the Asian financial crisis', Journal of Asia Pacific Economy, 8(2):157-79.

Walmsley, T.L., Betina, V.D. and Robert, A.M., 2000. A Base Case Scenario for the Dynamic GTAP Model, Centre for Global Trade Analysis, Purdue University, West Lafayette.

Wattanapruttipaisan, T., 2003. 'ASEAN-China Free Trade Area: advantages, challenges, and implications for the newer ASEAN member countries', ASEAN Economic Bulletin, 20(1):31-48.

Wong, J. and Chan, S., 2002. 'China's emergence as a global manufacturing centre: implications for ASEAN', Asia Pacific Business Review, 9(1):7994.

--, 2003. 'China-ASEAN Free Trade Agreement: shaping future economic relations', Asian Survey, 43(3):507-26.

World Bank, 1997. China 2020: development challenges in the new century, The World Bank, Washington, DC.

World Trade Organization, 2001. Accession of the People's Republic of China, decision of 10 November 2001, World Trade Organization, Geneva.

Yu, W., Hertel, T., Preckel, P. and Eales, J., 2003. 'Projecting world food demand using alternative demand systems', Economic Modelling, 21:99-100. 


\section{Appendix}

Table A13.1 Tariff rates in China for its WTO accession, 2001-2010 (per cent)

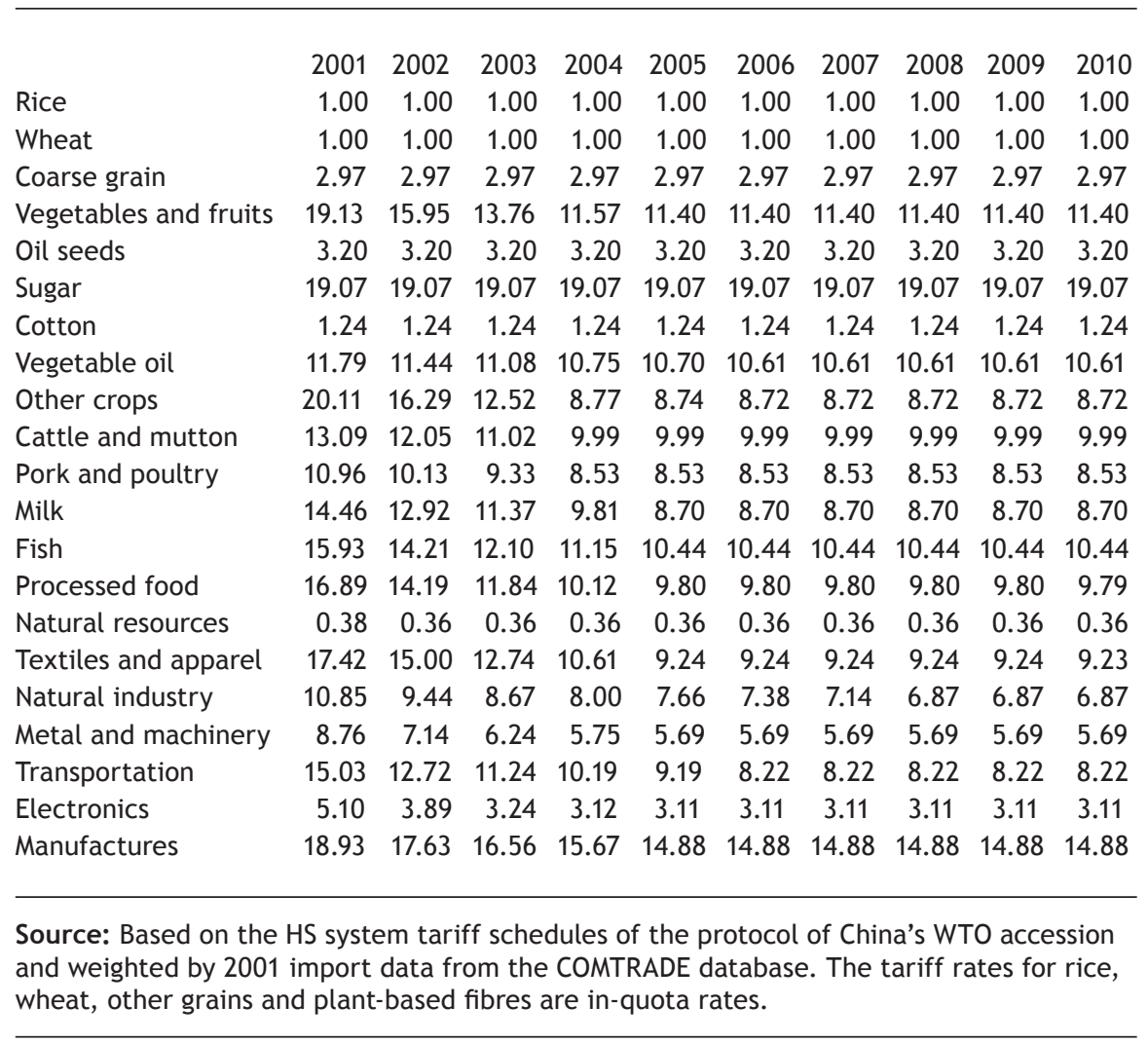


Table A13.2 Regional aggregations

Description

$\begin{array}{ll}\begin{array}{ll}\text { China } \\ \text { HK }\end{array} & \begin{array}{l}\text { Mainland China } \\ \text { Hong Kong, China } \\ \text { TW } \\ \text { JapKor }\end{array} \\ \text { ASEAN-old } & \begin{array}{l}\text { Taiwan, China } \\ \text { Japan and South Korea } \\ \text { ASEAN old members }\end{array} \\ \text { ASEAN-new } & \text { ASEAN new members } \\ \text { OthAsia } & \text { Other Asia } \\ \text { Australia } & \text { Australia and New Zealand } \\ \text { NAFTA } & \text { North American Free Trade } \\ \text { SAM } & \text { Agreement area } \\ & \text { South and Central America }\end{array}$

EU15

CEEC

ROW
European Union

Central European Associates

Rest of World
Original GTAP Version 6

regional aggregation

Mainland China

Hong Kong, China

Taiwan, China

Japan, South Korea

Indonesia, Malaysia, the Philippines,

Thailand, Singapore

Vietnam, rest of Southeast Asia

India, Bangladesh, Sri Lanka, rest of

East Asia, rest of South Asia

Australia

Canada, United States, Mexico

Central America, Caribbean, Colombia, Peru, Venezuela, rest of Andean Pact, Argentina, Brazil, Chile, Uruguay, rest of South America, rest of Caribbean

Austria, Belgium, Denmark, Finland, France, Germany, United Kingdom, Greece, Ireland, Italy, Luxembourg, Netherlands, Portugal, Spain, Sweden Hungary, Poland, Albania, Bulgaria, Croatia, Cyprus, Czech Republic, Malta, Romania, Slovakia, Slovenia, Estonia, rest of Europe Switzerland, New Zealand, rest of EFTA, Turkey, rest of Middle East, Morocco, rest of North Africa, Malawi, Mozambique, Tanzania, Zambia, Zimbabwe, other southern Africa, Uganda, rest of Sub-Saharan Africa, former Soviet Union, Botswana, rest of SACU, Russia, rest of world 
Table A13.3 Sector aggregation

Original GTAP Version 6 sector aggregation

Rice

Wheat

Coarse grain

Vegetables and fruits

Oil seeds

Sugar

Cotton

Other crops

Vegetable oil

Cattle and mutton

Pork and poultry

Milk

Fish

Processed food

Natural resources

Textiles and apparel

Natural industry

Metal and machinery

Transportation

Electronics

Manufactures

Services
Paddy rice, processed rice

Wheat

Cereals, grains nec

Vegetables, fruit, nuts

Oil seeds

Sugar cane, sugar beet, sugar

Plant-based fibres

Crops-nec

Cattle, sheep, goats, horses and their meat

Animal products nec, wool, silk-worm cocoons, meat

products

Raw milk, dairy products

Fish

Food products nec, beverages, tobacco products

Forestry, coal, oil, gas, minerals nec

Textiles, clothing apparel, leather products

Wood products, paper products and publishing,

petroleum, coal products; chemical, rubber and plastic

products; mineral products

Ferrous metals, metals nec, metal products, machinery

and equipment nec

Motor vehicles and parts, transport equipment nec

Electronic equipment

Manufactures nec

Electricity, gas manufacture, distribution, water, construction, trade, transport nec, sea transport, air transport, communication, financial services nec, insurance, business services nec, recreation and other services, public administration/defence/health/education, dwellings

Note: nec - not elsewhere classified 
Table A13.4 Adjusted own-price and income elasticities for China

\begin{tabular}{lccccc} 
& \multicolumn{3}{l}{ Own-price elasticity } & \multicolumn{3}{c}{ Income elasticity } \\
& GTAP & Adjusted & GTAP & Adjusted & 2006 \\
& 2001 & 2001 & 2001 & 2001 & \\
Rice & & & & & \\
Wheat & -0.08 & -0.27 & 0.4 & 0.04 & 0.03 \\
Coarse grain & -0.07 & -0.29 & 0.4 & 0.06 & 0.05 \\
Vegetables and fruits & -0.06 & -0.26 & 0.4 & -0.35 & -0.35 \\
Oil seeds & -0.12 & -0.65 & 0.4 & 0.53 & 0.53 \\
Sugar & -0.06 & -0.57 & 0.4 & 0.42 & 0.41 \\
Cotton & -0.07 & -0.60 & 0.42 & 0.55 & 0.5 \\
Other crops & -0.22 & -0.50 & 1.06 & 1.06 & 1.06 \\
Vegetable oil & -0.18 & -0.57 & 0.87 & 0.42 & 0.41 \\
Cattle and mutton & -0.06 & -0.65 & 0.4 & 0.53 & 0.53 \\
Pork and poultry & -0.25 & -0.78 & 1.23 & 0.66 & 0.65 \\
Milk & -0.34 & -0.65 & 1.23 & 0.56 & 0.55 \\
Fish & -0.25 & -0.89 & 1.23 & 1.05 & 1.04 \\
Processed food & -0.28 & -0.67 & 1.23 & 0.8 & 0.79 \\
Natural resources & -0.28 & -0.55 & 0.87 & 1.12 & 1.04 \\
Textiles and apparel & -0.26 & -0.26 & 1.26 & 1.26 & 1.26 \\
Natural industry & -0.29 & -0.29 & 1.06 & 1.06 & 1.06 \\
Metal and machinery & -0.33 & -0.32 & 1.25 & 1.25 & 1.25 \\
Transportation & -0.29 & -0.29 & 1.25 & 1.25 & 1.25 \\
Electronics & -0.28 & -0.28 & 1.26 & 1.26 & 1.26 \\
Manufactures & -0.28 & -0.28 & 1.25 & 1.25 & 1.25 \\
Services & -0.28 & -0.28 & 1.25 & 1.25 & 1.25 \\
& -0.49 & -0.48 & 1.15 & 1.15 & 1.15 \\
\hline & & & & & \\
\hline & & & & &
\end{tabular}

Source: Estimated by the Centre for Chinese Agricultural Policy (CCAP). 
Table A13.5 Summary of tariff equivalents for China, 2001-20

\begin{tabular}{|c|c|c|c|c|c|c|c|c|}
\hline & \multicolumn{4}{|c|}{ Import tariff equivalents (\%) } & \multicolumn{4}{|c|}{ Export tariff equivalents (\%) } \\
\hline & GTAP & 2001 & 2006 & 2010 & GTAP & 2001 & 2006 & 2010 \\
\hline Rice & 1.0 & 1.0 & 1.0 & 1.0 & 0 & -9 & -5 & -3 \\
\hline Wheat & 1.0 & 1.0 & 1.0 & 1.0 & 0 & 0 & 0 & 0 \\
\hline Coarse grain & 87.8 & 3.0 & 3.0 & 3.0 & 0 & 31 & 0 & 0 \\
\hline Vegetables and fruits & 24.8 & 19.1 & 11.4 & 11.4 & 0 & -11 & -6 & -4 \\
\hline Oil seeds & 101.0 & 3.2 & 3.2 & 3.2 & 0 & 0 & 0 & 0 \\
\hline Sugar & 18.6 & 19.1 & 19.1 & 19.1 & 0 & 0 & 0 & 0 \\
\hline Cotton & 1.6 & 1.2 & 1.2 & 1.2 & 0 & 14 & 0 & 0 \\
\hline Other crops & 12.8 & 11.8 & 10.6 & 10.6 & 0 & 0 & 0 & 0 \\
\hline Vegetable oil & 17.0 & 20.1 & 8.7 & 8.7 & 0 & 0 & 0 & 0 \\
\hline Cattle and mutton & 15.3 & 13.1 & 10.0 & 10.0 & 0 & -8 & -5 & -3 \\
\hline Pork and poultry & 10.6 & 11.0 & 8.5 & 8.5 & 0 & -21 & -11 & -6 \\
\hline Milk & 19.9 & 14.5 & 8.7 & 8.7 & 0 & 0 & 0 & 0 \\
\hline Fish & 11.5 & 15.9 & 10.4 & 10.4 & 0 & -20 & -10 & -7 \\
\hline Processed food & 21.6 & 16.9 & 9.8 & 9.8 & 0 & -10 & -6 & 0 \\
\hline Natural resources & 0.3 & 0.4 & 0.4 & 0.4 & 0 & 0 & 0 & 0 \\
\hline Textiles and apparel & 19.4 & 17.4 & 9.2 & 9.2 & -5 & 0 & 0 & 0 \\
\hline Natural industry & 12.3 & 10.9 & 7.4 & 6.9 & 0 & 0 & 0 & 0 \\
\hline Metal and machinery & 11.4 & 8.8 & 5.7 & 5.7 & 0 & 0 & 0 & 0 \\
\hline Transportation & 20.5 & 15.0 & 8.2 & 8.2 & 0 & 0 & 0 & 0 \\
\hline Electronics & 10.1 & 5.1 & 3.1 & 3.1 & 0 & 0 & 0 & 0 \\
\hline Manufactures & 17.4 & 18.9 & 14.9 & 14.9 & 0 & 0 & 0 & 0 \\
\hline Services & 0 & 19.0 & 9.0 & 9.0 & 0 & 0 & 0 & 0 \\
\hline
\end{tabular}

Source: The import tariff equivalents, excluding services, were calculated by the authors; the estimates for services are from Tongeren, F. and Huang, J., 2004. China's food economy in the early 21st century, Report, No.6.04.04, Agricultural Economics Research Institute (LEI), The Hague; Francois, J.F. and D. Spinanger, 2004. 'WTO accession and the structure of China's motor vehicle sector', in D. Bhattasali, S. Li and W. Martin (eds), China and the WTO: accession, policy reform, and poverty reduction strategies, The World Bank and Oxford University Press, Washington, DC; the export tariff equivalents are based on the estimates by the Centre for Chinese Agricultural Policy (CCAP). 